\title{
The centrality of partnership between local congregations and Christian development organisations in facilitating holistic praxis
}

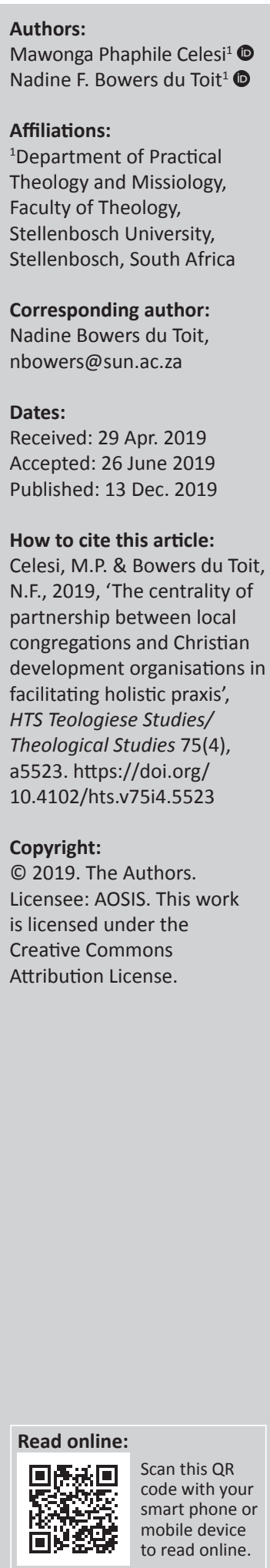

Central to the argument of this article is the view that enhanced partnership between local congregations and Christian development organisations has the potential to facilitate holistic congregational praxis. In most cases, these entities of the church are found in the same locality, and therefore, need to define how they can together play a bigger and meaningful role in the transformation of their community. Bound by their faith mandate, working together as partners as opposed to competing with each other, they will find strength in each other and portray a good image of the Christian community in society. Guided by partnership ethos of trust, equality and mutual respect, they can both play a leading role in the nation-building project of South Africa. The article therefore explores the findings of the 'Faith Matters' study with regard to the relationship between local congregations and Christian development organisations and seeks to make recommendations with regard to ways in which this partnership could be strengthened.

Keywords: partnership; local congregations; Christian development organisations; holistic congregational praxis; Missio Dei; dualism; faith mandate; self-reliance.

\section{Introduction}

This article gives attention to the partnership between local congregations and Christian development organisations (CDOs). Findings of a portion of the study in the 'Does Faith Matter' (FM) research project about the nature of the partnership between local congregations and CDOs in the Cape Metropolitan area indicate that there is a partnership between these two entities, although the nature of their relationship is often not adequately explored. In most cases, these faith-based actors are found in the same locality, and therefore, the need arises to define how they can together play a bigger and more meaningful role in the transformation of the community. The trust that the church enjoys provides the necessary credibility for local congregations and CDOs to facilitate network formation especially in South African societies, where levels of distrust are high (Burger \& Van der Watt 2010:396). Based on this trust, they should define the reason for their existence in their local communities. ${ }^{1}$ As God's representatives, they must allow themselves, as salt and light (Mt 5:13-16), to be instruments of healing for broken relationships in a country that is marred by poverty, inequality and division. Local congregations and CDOs are found where people are especially the poor, and this partnership should help in the affirmation of the poor as worthy change agents.

They also have the potential to facilitate holistic congregational praxis. The collaboration advocated for in this work is not only beneficial to them as they strengthen one another in ministry, but it serves as a witness to the unity of the church (Castillo 1992:1). In addition to this, the building of partnerships, through sharing of resources, information and skills that are available to each partner, is essential in effecting change within this context (Bush 1992:6; Hendriks 2004:190). This article begins by exploring a brief definition of partnership and identifying the most issues in the partnership between local congregations and CDOs via a short literature review. This section is followed by the methodology of the 'Faith Matters' project and a discussion of its findings. The final section makes concrete recommendations as it is how the partnership between local congregations and CDOs could be enhanced.

1.Faith-based organisations (FBOs) also enjoy the respect of people at grassroots level because of their visibility and involvement in society especially with regard to programmes related to poverty alleviation, for example, HIV and AIDS pandemic, bereavement, orphanages and feeding schemes (Conradie \& Field 2016:21). It is also argued that FBOs have large constituencies, and that puts them in a position to play a powerful role in advocacy and public awareness (Ferris 2005:325). In SA, the church is seen as an influential role player in the non-governmental organisation (NGO) sector, on average, reaching $54 \%$ of the Christian population weekly (ElgelaarMeets, Gomulla \& Gelden Huys 2010:54). There is also a distinctive value component that the church brings (Swart 2005:26), but Christians in South Africa are not seen to be part of the mainstream voices forming and informing public opinion (Smit 2008:103).

Note: Faith-Based Organisations, sub-edited by Nadine Bowers du Toit (Stellenbosch University), Vhumani Magezi (North-West University) and Elisabet le Roux (Stellenbosch University). 


\section{Exploring the partnership between the local congregations and Christian development organisations}

An understanding of the Missio Dei is crucial in facilitating partnerships towards holistic praxis. It is in recognising this as God's activity (Bosch 1991:391) that local congregations and CDOs as manifestations of the church in the local setting are to act as God's agents. Participating in the Missio Dei is to journey towards the reign of God and to receive the kingdom of God as and when it breaks into our reality (Marais 2017:375). For this reason, the church can only be authentically 'in Missio' when in obedience to God (Bevans \& Schroeder 2004:290). Therefore, a ministry that flows from a healthy relationship with God, whose nature is missional, is characterised by knowing that the Church does not exist for itself but for the world in which it is found, and that we are not here to serve ourselves but the world (Burger 2017:25).

Ajulu (2010:166) notes that a holistic mission, in general, is God's mission (Missio Dei) that involves everything God does in establishing his kingdom in the whole world in all its fullness. In obedience, local congregations and CDOs should allow the movement of God to express the power of God over history (Wright 2006:62), and that obedience should manifest in praxis, as they partner with the very people they seek to minister to, through word and deed. Knowing that God already exists in the community in which they serve (Samuel \& Sugden 1999:274), they should develop strategies to increase people's capacities to meet their own needs through self-reliant actions (Erasmus \& Mans 2010:368).

The term 'partnership' has many synonyms within the Christian community, such as 'relationship', 'fellowship', 'sharing', 'commonality' and 'koinonia'. Kritzinger (2007:28) argues that Jesus erected signs of the kingdom both through his sacrificial caring and healing (Diakonia), and called and nurtured disciples as the beginning of his new people (koinonia). Healthy partnership, built upon the foundation of partnership ethos of trust, equality, unity and respect for people and affirming the Missio Dei as both a means and an end of mission, is essential and this is no different with regard to the partnership between the local congregation and the CDO. By acknowledging that the building of partnerships is a process, not an event, partners walk and work together towards the common goal. In the process of engagement between partners, trust develops. This process also includes dialogue, as it is contended that meaningful dialogue rests on the need for trust, honesty and the ability to disagree (Pitchford \& Henderson 2008:71). The process also speaks about infusing and maintaining mutual respect as an element of trust. According to Butler (2005:47), ministry partnerships are only effective and durable as they build trust, work actively at restoring relationships and celebrate diversity within unity.

One of the central theological issues with regard to partnership between local congregations and CDOs is a dualistic approach to the gospel mandate. This dualistic approach often leads to the notion that it is the local church alone that carries the gospel mandate, and that CDOs and other development organisations only play a complementary role. The dominant view in Christian circles is therefore that local congregations are associated with the so-called holy or sacred, which emphasises the importance of the unseen, while the CDOs are associated with the less holy or secular and less important physical world. This often leads to an element of distrust and an attitude of 'us versus them', which leads to the failure of many collaboration efforts between CDOs and local congregations. A study that was conducted in the Cape Flats reveals that one CDO expressed frustration that local congregations often did not express social support for issues that affected the community, but instead focused on the 'heavenly' or spiritual pursuits of evangelistic campaigns (Bowers du Toit 2010a:436).

As a result of this dualistic theology, in some instances, CDOs are not afforded the status that is afforded the local congregations. They (CDOs) are not seen as fully representative of the church, hence the use of terms, such as 'para-churches', 'shadow-churches' or church organisations, and so on. The issue of resources and control can be a hindrance to the partnership or a cause for division. In this regard, Morgensen (2017:125) thinks that it is incumbent on mission societies and CDOs to see themselves as part of the church. Local congregations and CDOs must therefore pull their resources together in addressing issues of poverty and marginalisation of the 'least of these', realising that no one group has full capability and resources to do the work of development (Castillo 1992:1). Equality is an ethos upon which any partnership should be found. The reciprocal character of partnership and the mutuality of encouragement as crucial aspects of any partnership should be evident, as partners know that sharing of resources comes in both ways and not one way, where one partner is the giver and the other is the receiver (Van Deventer 2009:156). Abilities and strengths of partners may be different, but at the table of partnership, an equal status should be afforded to all partners, as in all good partnerships, the benefits flow in two directions (Bush \& Lutz 1990:32). A common understanding of the kingdom mandate can lead to a more holistic missional praxis, and subsequently, the mandate of CDOs is equal and important as that of local congregations; therefore, any argument from either side which seeks to advance or elevate one over the other must be refuted as divisive and lacking the spirit of partnership. The reality is that the urgency of the task requires that we put our efforts together; therefore, opportunities as well as inherent tensions over resources, control and recognition mean that the relationship has to be actively managed to ensure that these tensions are mitigated (James 2009:32).

In response to dualism, Myers (1999:120) notes that evangelism and social action are two sides of the same 'gospel coin' or two wings of the 'gospel bird'. The tension or 'the "thorniness" between the two mandates must, therefore, be understood as stemming from a division in the understanding of the mandate of mission' (Bowers du Toit 2010b:264). While the local congregation is affirmed by documents such as the Wheaton 
'83 Declaration, as a core agent of the kingdom mandate in local settings, it can and should play a crucial rolein affirming CDOs, by first recognising the crucial role played by these CDOs and by partnering with them on an equal basis recognising that both entities carry a kingdom mandate. Christian development organisations are an important role player as far as the Christian witness is concerned as they are often the ones dealing with the 'bread and butter' issues in society, such as crime, diseases, hunger and so on. Therefore, one of the essential steps on the road towards holistic missional praxis by both CDOs and local congregations is to work hard to find a balance between evangelism and social action and to recognise the gifts to the Body of Christ that each entity may bring in sharing the fullness of the gospel.

\section{Emerging findings from the questionnaire of the 'Does Faith Matter' research project \\ Methodology}

The data presented in this article stem from a research project entitled 'Does faith matter?: Exploring the role of faith-based organisations as civil society actors', which aimed to explore at the current and potential role of FBOs for transformation in South Africa (SA). It should be noted that the concept of the CDO was coined within the broader 'Does Faith Matter' research project to refer to formally registered organisations (NGO, trust and so on) that are Christian and based on grassroots to address issues of poverty and marginalisation. Throughout the project, the term CDO is used to refer to this type of FBO. The empirical findings of this article are derived from quantitative survey research, and existing FBO networks, as well as donor databases, were used to target CDOs as described. Electronic questionnaires were then sent to over 80 organisations in the Cape Metropole, which fitted this description with a response rate of around 42 responding to the questionnaires. The questionnaires were created using Survey Monkey and the electronic survey possessed a consent form on the cover page, which provided the capability to simply click for consent via the form. Ethical consent for the project was obtained via the University of Stellenbosch Ethics Committee. The study was conducted between 2016 and 2018 and one of its aims was to explore the partnership between local congregations and CDOs.

\section{Ethical consideration}

The project received ethical clearance from the University of Stellenbosch (clearance number: SU-HSD-003625).

\section{Findings \\ Areas in which these Christian development organisations operate}

Figure 1 ('Does Faith Matter' research project 2018) indicates that some CDOs work in more than one area in the Cape Metro. The majority of the CDOs that responded are in the Cape Flats, close to $60 \%$, followed by the $40 \%$ working in the

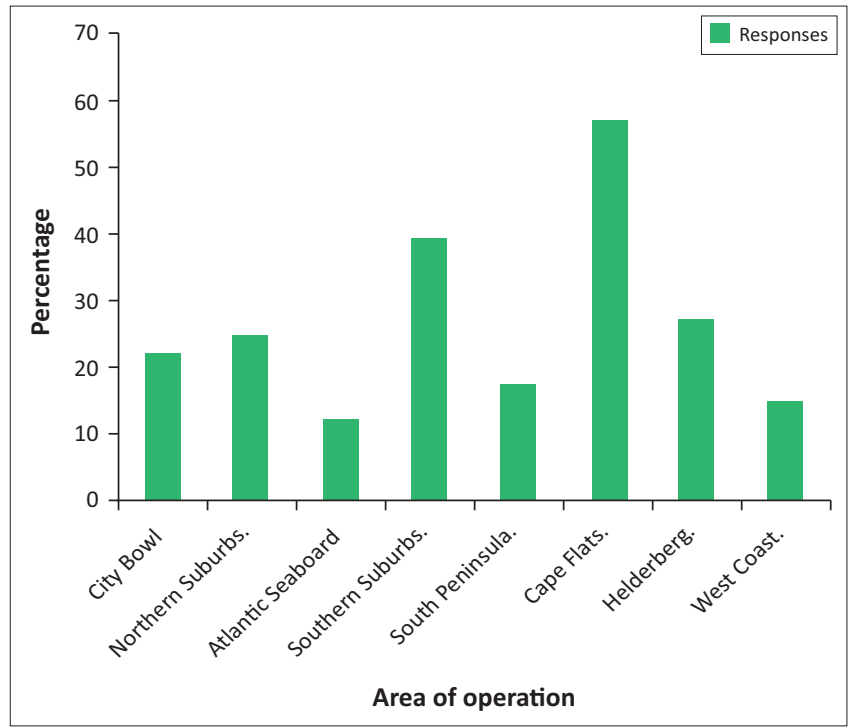

FIGURE 1: Areas in which these Christian development organisations operate.

Southern Suburbs and others ranging between $20 / 30 \%$ and below. The majority of people living in the Cape Flats are poor and live on low levels of income and the churches in these areas are not immune to these poverty conditions. The study indicates that most CDOs operate in areas where poverty seems to be more prevalent, which is not an unexpected scenario as development is mainly a response to human need. The study conducted by Bowers du Toit (2017:3) also shows that in the name of unity, churches from wealthy areas saw a need to partner with churches in the poor areas, the majority of which are found in the Cape Flats.

\section{Areas of focus for Christian development organisations}

As Figure 2 ('Does Faith Matter' research project 2018) indicates, CDOs focus on a range of pressing issues in society. It is of great interest to note that more than $60 \%$ of the responses indicate that the focus is on Christian discipleship. Somehow this is contrary to the view that says CDOs mainly focus on social issues as compared to spiritual issues.

Second to Christian discipleship is youth development and education at about $59 \%$. The graph shows that job skills and job training are at $40 \%$. The other interesting observation is that early childhood development and advocacy are just a little more than $30 \%$. It would be interesting to find the reason behind the fact that responses of CDOs, whose focuses are primary healthcare and home-based care, rehabilitation of people living and working on the streets, abused women and children, nutrition and feeding schemes, seem to be the lowest in the graph. In the study that was conducted by Erasmus (2010:308) at Mbekweni location, in the Boland area of the Western Cape, where the problem of unemployment is extensive, and respondents felt strongly (70.9\%) that churches should play a role in preventative action, namely, through skills training and job creation. The preventative approach means being proactive rather than being reactive. The observation here seems to 


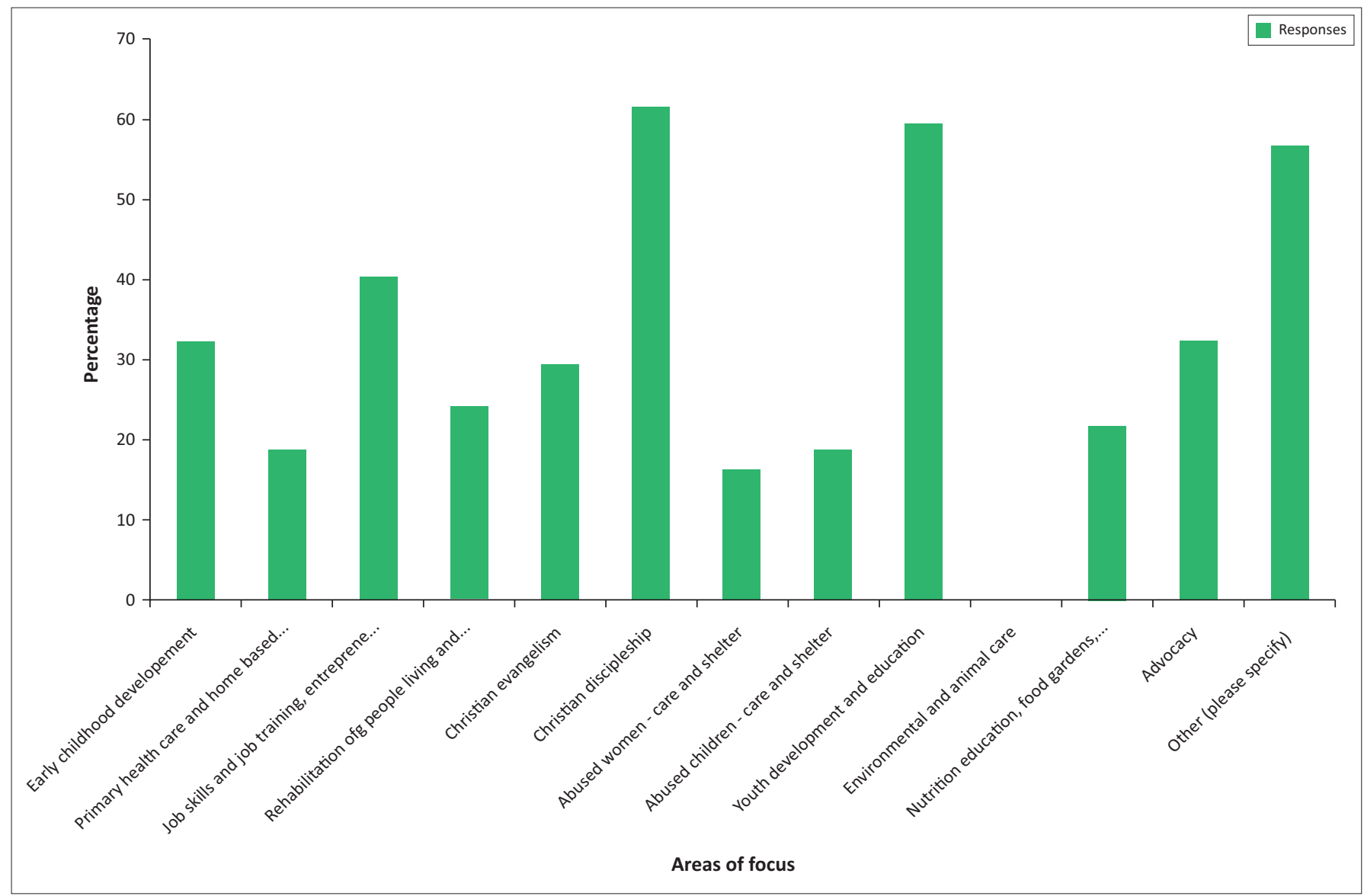

FIGURE 2: Areas of focus for Christian development organisations.

suggest that CDOs have adopted a proactive stance to development as opposed to a reactive one. This is because all the aspects that seem to top on the focus list are based on empowering people to stand on their own and claim the development journey. It is a concern, however, that there is a $0 \%$ response on CDOs that work with environment and animal care especially at a time where climate change is a world concern.

\section{Who funds these Christian development organisations?}

CDOs had to respond to the following three questions: What sources of funding do you have? What does each contribute? What percentage of your funding do they provide (to make up a total of $100 \%)$ ?

It is a concern to note that the majority $(86,96 \%)$ of these CDOs depend mainly on institutional funding from other countries (e.g. USAID, DFID) or other international donor organisations (44\%), as shown in Figure 3 ('Does Faith Matter' research project 2018). About $23 \%$ of the CDOs receive funding from the South African government and almost 14\% from Trusts, Lotto. Christian development organisations indicated that they have to downplay or change their Christian identity to secure funding from donors such as government, trusts, lotto, business and overseas donors. Almost $15 \%$ of the funding comes from South African business and 13\% comes from other individuals in SA. Again, four of the 42 (about 10\%) CDOs

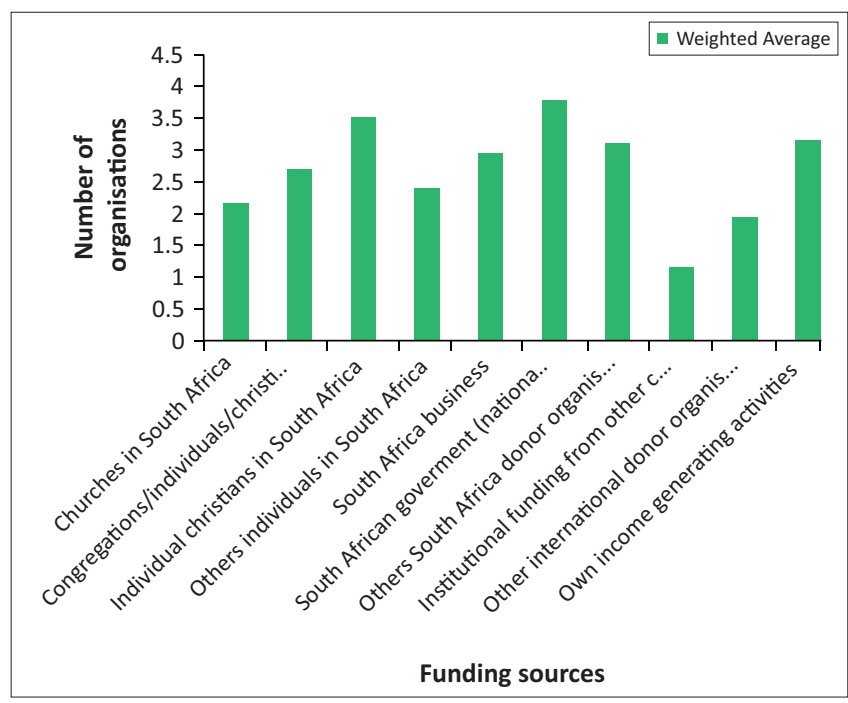

FIGURE 3: Who funds these Christian development organisations?

indicate that they receive money from congregations or individual or Christian donor organisations from other countries. Only about $20 \%$ of the CDOs indicated that they receive funding from churches in SA and almost $17 \%$ get money through their fund-generating activities.

We note that even though CDOs receive funding from more than one source, there is still a heavy dependency on donors 
from outside SA. It would be interesting to note what the further study of the FM project reveals concerning how the relationship between these donors and the CDOs affects the operations of these CDOs in as far as setting the agenda and focus is concerned. To secure funding from almost all the donors who are not Christian, such as government, trusts, lotto and overseas donors, CDOs have to downplay or change their identity. It is worth indicating that only 17 of the 42 CDOs responded, while 24 chose not to respond. This could be interpreted as an indication that CDOs have to work hard towards independence and self-reliance in order not to compromise their Christian identity and purpose.

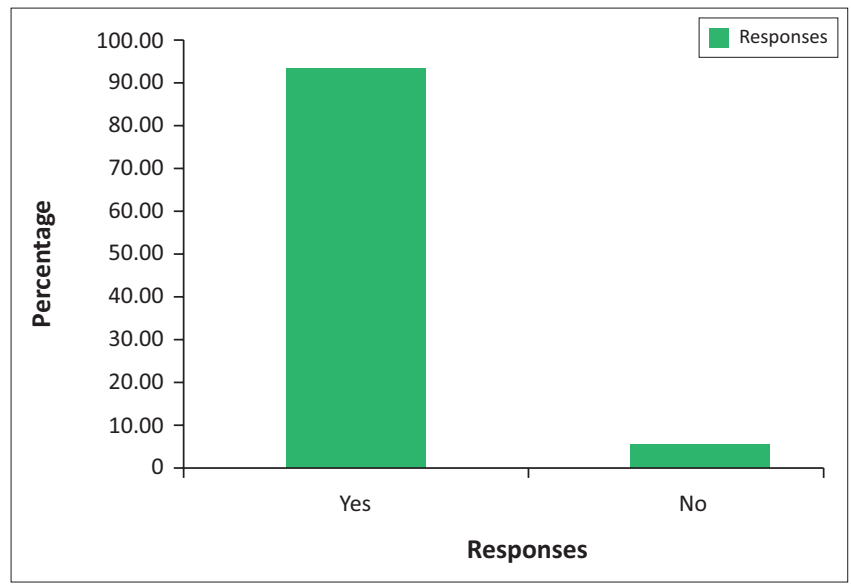

FIGURE 4: Demonstrating whether the Christian development organisation has a relationship with any local congregations.
Christian development organisations that depend on programmes that are self-generated, self-sustaining and selfdriven are free to express their Christian identity in society as opposed to those that depend on outside church donors who may demand practices that may even operate contrary to Christian values. The ideal situation developmentally is a situation where CDOs could be self-sustainable and where financial support from local congregations continues to grow. Even though local congregations can have a measure of influence on decisions taken in the CDOs, it is unlikely that they would demand the changing or downplaying of Christian identity.

\section{On whether the Christian development organisation has a relationship with any local congregations}

While the majority of CDOs (as indicated in Figure 4; 'Does Faith Matter' research project 2018) reported that they have a relationship with the local congregation and they receive support from them in more than one form, the support that many of these CDOs get is through volunteers, prayer support and discipleship programmes with little financial support.

It is good to note that $94 \%$, that is, 33 out of the 42 CDOs, responded by saying that they have a relationship with a local congregation. Questions can be raised as to why some CDOs could not respond with either a yes or a no. Only two responded by saying no that they do not have a relationship with a local congregation. The overwhelmingly positive

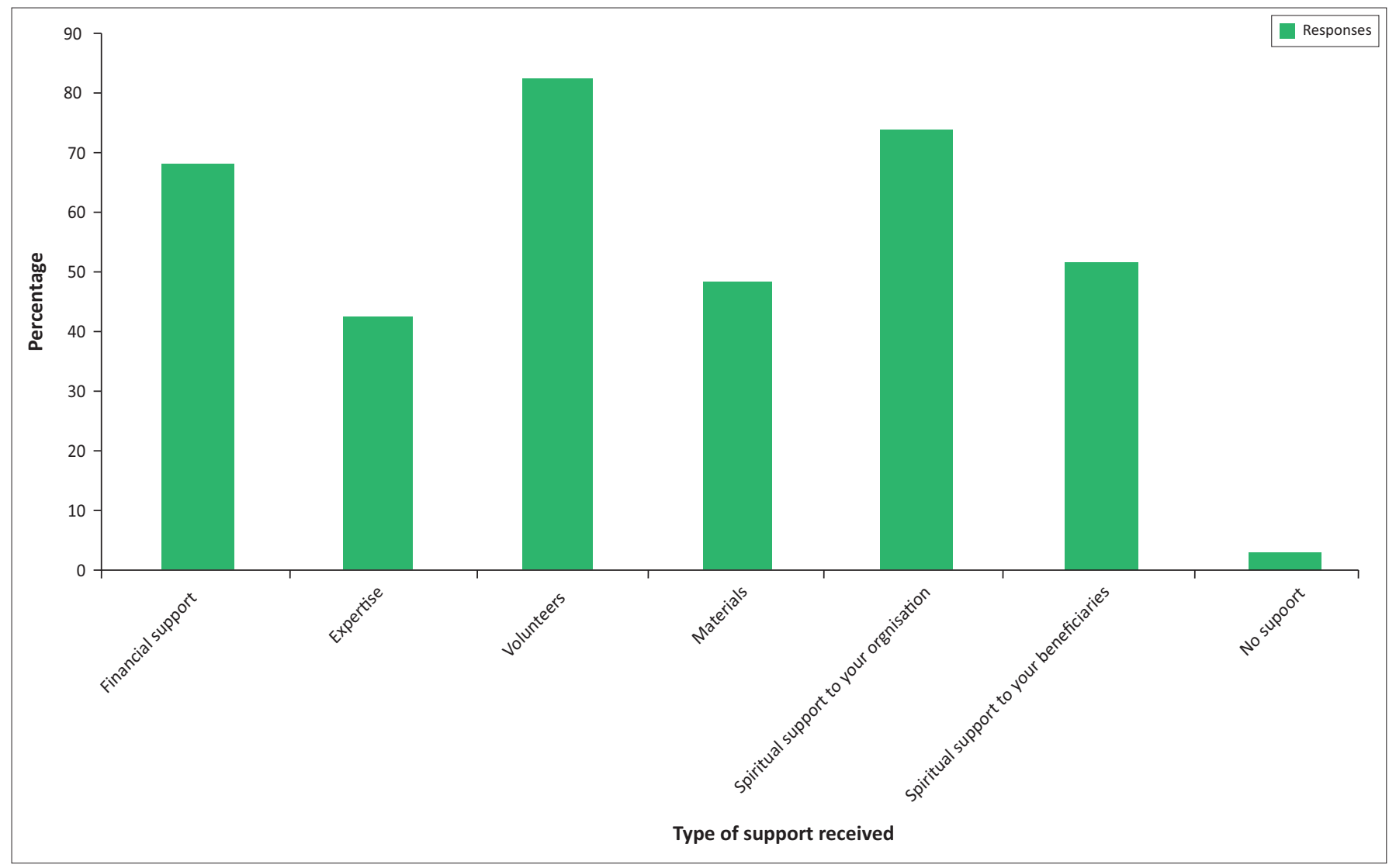

FIGURE 5: In which ways do Christian development organisations get support from local congregations? 
response is certainly welcomed and it additionally enhances more interest concerning the topic of this study, as we explore whether the relationship or partnership between these CDOs and those local congregations is healthy or not, or better still the areas of operation it touches or translates to. On the nature of relationship and interaction, about 9 of the 42 CDOs chose not to respond, while 3 out of $42(9,38 \%)$ relate to a congregation that is close to them, of which 9 of the 42 (28, 13) were founded by a congregation. The study also shows that a big number $(20 / 42)$ has links to congregations through members of the congregation volunteering or working in the CDO. This is a testament to the fact that churches or FBOs are hailed for their power to mobilise and produce people who are willing to work as volunteers. In his study in the Paarl Area, Erasmus (2010:384) found that out of 24 congregations that were sampled, $17(71 \%)$ render services ranging from immediate relief to preventative action, and in light of this work, it is important to note that those congregations depended heavily on volunteers to do the work.

\section{In which ways do Christian development organisations get support from local congregations?}

Christian development organisations receive support from local congregations in more than one form or way (Figure 5; 'Does Faith Matter' research project 2018). The power of volunteerism in the church or FBOs is evident with more than $85 \%(29 / 42)$ of the CDOs, indicating that they receive support from local congregations through volunteers.

It is interesting to observe that 24 out of 42 (more than $70 \%$ ) indicate that they receive financial support from local congregations. It may be interesting to know how much of that, in fact, contribute to their overall budget. One would, however, be justified in assuming that it is very low as only six of them earlier indicated that they receive money from churches in SA. This is particularly interesting in this study that seeks to see enhancement of the partnership between local congregations and CDOs. The view is that one of the ways to enhance and strengthen partnerships will need to be about financial support. Support through expertise and material is at $44 \%$ and $50 \%$, respectively. As expected, spiritual support to the organisation and beneficiaries is relatively high at $76 \%$ and $52 \%$, respectively. On the graph about what the area of work is the focus of the CDOs, Christian discipleship was on top with more than $60 \%$. This confirms that the faith conviction of these CDOs influences how they conduct themselves. Interestingly, only about 3\% indicate that they receive no support at all, which is one out of the $42 \mathrm{CDOs}$ that responded. As expected, 27 CDOs out of the $42(79,41 \%)$ responded by saying that they would greatly appreciate financial support. Volunteers are also in high demand, at about $62 \%$, which is about 21 CDOs that indicated the need. The need for support with expertise, spiritual support for the organisations or their beneficiaries is relatively high at about $60 \%$. The partnership between local congregations and CDOs is not therefore translating into tangible resources such as money and high-level expertise, and therefore, while the power of volunteerism in the church or FBOs is evident in this study, many of these volunteers could be lacking in terms of education and skills.

\section{What the Christian development organisations do to support local congregations?}

Figure 6 ('Does Faith Matter' research project 2018) is an indication of the work and collaborative efforts by CDOs to local congregations. It is interesting to see training being

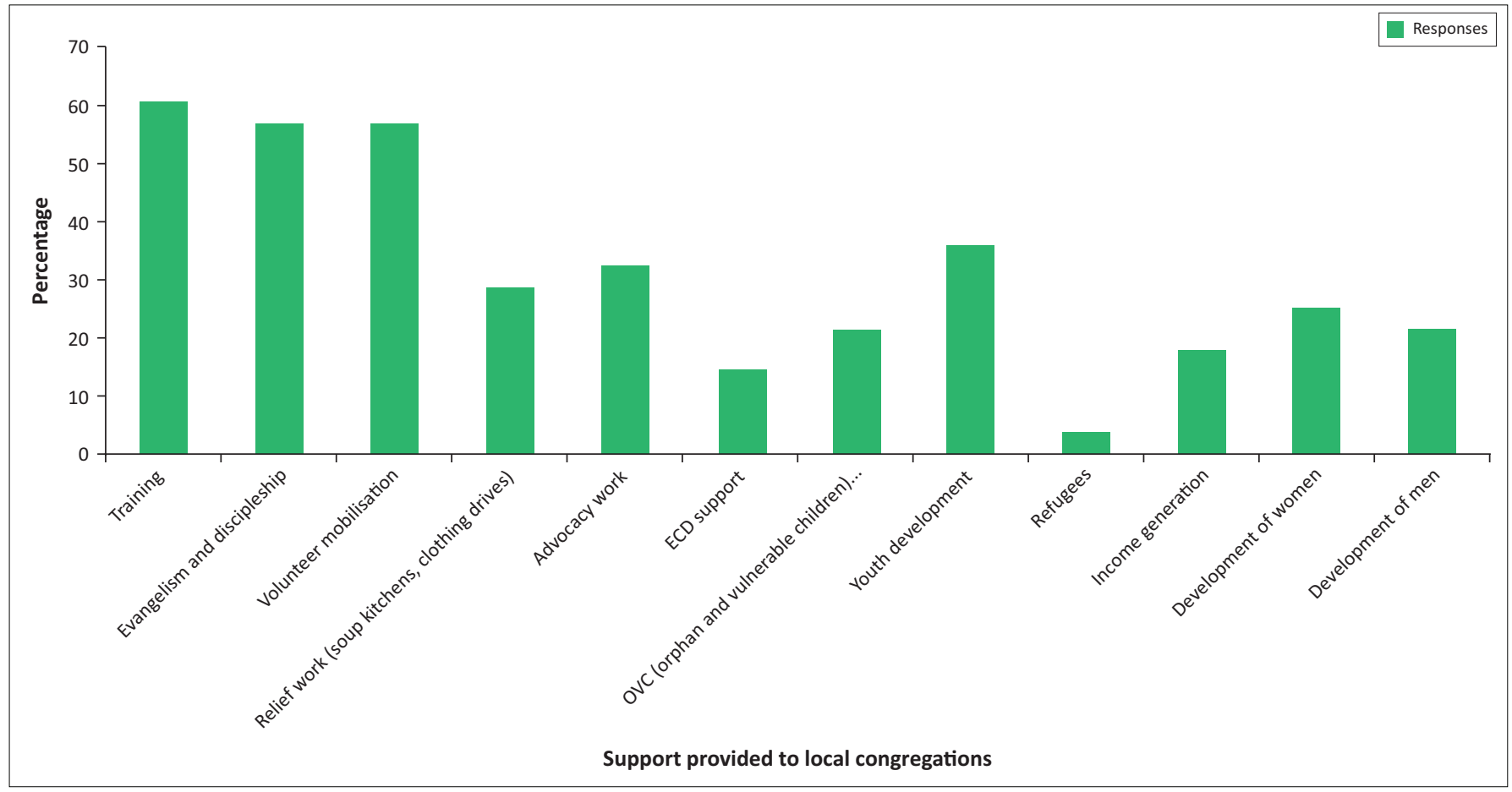

FIGURE 6: What the Christian development organisations do to support local congregations? 
an area of focus at almost $61 \%$ followed by evangelism and discipleship as well as mobilisation all at $57.14 \%$.

Youth development is at $35 \%$, and advocacy work is at $32 \%$, while the development of women and men is at $25 \%$ and $21 \%$, respectively. Relief work (soup kitchens, clothing drives) is at $28.57 \%$, while orphan and vulnerable children (OVC) programmes are at $21 \%$. Income-generating efforts stand at $17.86 \%$, while refugees-related initiatives are at $4 \%$. It is interesting to note that 13 of the $42 \mathrm{CDO}$ did not respond at all. The study indicates that most CDOs operate in the areas where poverty seems to be more prevalent, for example, the Cape Flats.

In the study, we note that many CDOs indicate that their focus is on Christian discipleship and evangelism, something which is mostly associated with local congregations. In some ways, this is in contrast to the view that CDOs mainly focus on social issues rather than spiritual issues.

\section{Recommendations towards enhancement of the partnership between congregations and Christian development organisations}

This section explores addresses, in the form of concrete recommendations, the ways in which both the 'thorniness' that may arise from the division in mission mandate as highlighted, as well as the findings from the FM study regarding the current relationship between congregations and CDOs, can be addressed. These recommendations are intended to help both local congregations and CDOs with practical ways in which they can build healthy and strong relationships towards the holistic mission, as they enable God's vision of society to be actualised in all relationships. It is also important that local congregations and CDOs must consider their context, which is African, a context and a view of life that is holistic just like the biblical world view, where the physical world is never understood as being disconnected or separate from the spiritual world and the rule of the God who created it (Myers 1999:8). African people are relational and humane; therefore, local congregations and CDOs should work towards the restoration or enhancement of a more humane and peaceful society.

Theological dualism must be confronted: Both CDOs and congregations have a mandate to address the whole person through the whole gospel, and no mandate (social or spiritual) is more important than the other. Indeed, God who is in fellowship with himself expects the church to live in fellowship with him, with one another as a Koinonia, with people in the community and with nature as a whole, and this is the foundation for all partnerships in ministry if the goal of transformation is to become a reality.

Local congregations and Christian development organisations must complement one another by focusing on their specialisations and strengths: Before looking for more collaborative efforts, local congregations and CDOs should start by looking at both the positives and the negatives of their relationship and then capitalise on the positives as they map a way forward. The specialisations of congregations and CDOs focusing their emphasis on the different sides of the coin (spiritual and social) should be a unifying factor as opposed to a dividing factor, as they complement one another. Both local congregations and CDOs need each other in ministry by virtue of belonging to the same faith and, by implication, having one mandate, which is the establishment of God's kingdom on earth. Both local congregations and CDOs have to not only see themselves as equal partners but to know that equality is something they have to work towards. Local congregations and CDOs play different roles, and comparing them is an unnecessary exercise, as each operates according to its strengths and targets.

Current collaboration with regard to volunteerism and spiritual support should be encouraged: Although the FM study findings show that there are collaboration efforts and partnership between local congregations and CDOs, there is also evidence that those partnerships revolve around issues such as volunteerism, prayer and discipleship efforts, but there is little translation to tangible issues such as finances and expertise. While encouraging and harnessing the power of volunteerism in SA, because churches or CDOs are hailed for their power to mobilise and produce people who are willing to work as volunteers, there is a need to focus and strengthen other practical means of partnering.

Congregations should consider supporting Christian development organisations more concretely in terms of financial support: The fact that CDOs do not receive significant financial support from local congregations often means that their faith identity could be put at risk. It is therefore recommended that local congregations consider the financial support of CDOs more seriously to free CDOs from the constraints imposed by secular donors who may request that they 'downplay' their faith ethos.

Congregations could bridge socio-economic inequality through a partnership with Christian development organisations: It is clear from the findings that CDOs are often positioned where the need is greatest geographically and are working with the poorest in the city. In SA, this can also be an opportunity for wealthier congregations estranged from poverty to address issues of poverty and disadvantage - this could be helpful to strengthen efforts of CDOs engaged in poorly resourced areas.

Find or create fellowship initiatives and exchange of expertise between congregations and Christian development organisations: One of the ways that can help partnership between the local congregations and CDOs to grow is fellowshipping together. It is after this establishment of fellowships that the partnerships can be escalated to higher levels. Being together for fellowship helps partners to know each other and to know each other's specialities. Fellowship initiatives can easily translate to scenarios such as a CDO inviting ministers or key and influential members of the church to serve in its structures such as the board of directors or management committees. 


\section{Conclusion}

In almost three decades into democracy, SA as a country has an urgent cry for justice, equality, peace and reconciliation. This yearning for a revival of the spirit of reconciliation that the country experienced at the dawn of democracy under Nelson Mandela's leadership calls all partners to play their part. The church, as a trusted partner in society, through its entities, such as local congregations and CDOs can play a role in leading society in the space of nationbuilding and moral regeneration. Based on understanding the Missio Dei, and tapping into the spirit of Ubuntu, the church can affirm people as agents of change and journey with them in transformation as they seek to find their solutions. We should therefore guard against an overemphasis on the vertical relationship between people and God while neglecting the importance of the horizontal relationship between people (Bower du Toit 2010b:264; Peter 1998:62). While CDOs social programmes may help people with skills to survive or put food on the table, there is need to always remember that the goal of transformational development explores far more, as it encompasses the totality of life and seeks peace for not only the individual but also with regard to the community, environment and fallen structures of society. Local congregations and CDOs can in partnership become powerful agents of social change in addressing both the individual and structural brokenness of our relationships and to take lead towards reconciliation.

\section{Acknowledgements}

This article forms part of a National Research Foundation (NRF) Competitive Unrated Grant (CSUR150623120252 9918) project entitled 'Does faith matter?': Exploring the role of faith-based organisations as civil society actors. The opinions, findings and conclusions or recommendations expressed in this article are that of the researcher.

The study (2016-2018) seeks to explore the current and potential role of faith-based organisations for transformation in South African society. FBOs have been at the forefront of a growing interest in the intersection between religion and development and several studies have noted the potential of FBOs to 'add value' to development. This study focuses on better understanding the positioning of these faith-based organisations within South Africa. Fieldwork is being conducted in the Cape Metropole area of South Africa, and includes both quantitative and qualitative activities. This is a NRF-funded study, with Prof. Nadine Bowers Du-Toit as the lead investigater and Dr. Le Roux as a project collaborator.

\section{Competing interests}

The authors declare that they have no financial or personal relationships that may have inappropriately influenced them in writing this article.

\section{Authors' contributions}

N.F.B.d.T. was the research project leader and MTh supervisor and co-wrote the article. This work is a summary and an interpretation of research findings that were also submitted as an MTh thesis by M.P.C. at the Faculty of Theology at Stellenbosch University under the supervision of Prof. N.F. Bowers du Toit. This was performed as part of 'Does Faith Matter' research project, reflecting on the views of the Christian development organisations on how they think the partnership between them and local congregations should be.

\section{Ethical considerations}

This article followed all ethical standards for carrying out research without direct contact with human or animal subjects.

\section{Funding information}

Financial support was received from the NRF as part of an NRF Competitive Unrated Grant (CSUR150623120252 - 9918).

\section{Data availability statement}

Data sharing is not applicable to this article as no new data were created or analysed in this study.

\section{Disclaimer}

The views expressed in this article are those of the authors' own and not an official position of the institution or funder.

\section{References}

Ajulu, D., 2010, 'Development as holistic mission', in B. Woolnough \& W. Ma (eds.), Holistic mission God's plan for God's people, pp. 160-174, Regnum, Oxford.

Bevans, S. \& Schroeder, R., 2004, Constants in context: A theology of mission for today, Orbis, Maryknoll, NY.

Bosch, D.J., 1991, Transforming mission: Paradigm shifts in theology of mission, Orbis, Maryknoll, NY.

Bowers du Toit, N.F., 2010a, 'Action or apathy? Theological perspectives and their influence on the church's engagement with poverty. A case study from the Cape Flats', in I. Swart, H. Rocher, S. Green \& J. Erasmus (eds.), Religion and development in post-apartheid South Africa: Perspectives for critical engagement, pp. 431-446, Sun Press, Stellenbosch.

Bowers du Toit, N.F., 2010b, 'Moving from development to social transformation. Development in the context of Christian mission', in I. Swart, H. Rocher, S. Green \& J. Erasmus (eds.), Religion and development in post-apartheid South Africa: Perspectives for critical engagement, pp. 261-274, Sun Press, Stellenbosch.

Burger, C., 2017, 'Why we need the missional conversation in South Africa now', in C. Burger, F. Marais \& D. Mouton (eds.), Cultivating missional change: The future of missional churches and missional theology, pp. 20-34, Biblecor/BM, Wellington.

Burger, R. \& Van de Watt, C., 2010, 'Bridging South Africa's deep divides: Religious networks as a resource to overcome social and economic exclusion', in I. Swart, $\mathrm{H}$. Rocher, S. Green \& J. Erasmus (eds.), Religion and development in postapartheid South Africa: Perspectives for critical engagement, pp. 393-402, Sun Press, Stellenbosch.

Bush, L., 1992, 'In pursuit of true Christian partnership', in J.H. Kraakevik \& D. Welliver (eds.), Partners in the gospel: The strategic role of partnership in world evangelisation, pp. 1-17, World Evangelical Fellowship Missions Commission, Wheaton, IL.

Bush, L. \& Lutz, L., 1990, Partnering in ministry: The direction of world evangelism, Intervarsity Press, Westmont, IL.

Butler, P., 2005, Well connected: Realising power, restoring hope through kingdom partnerships, Authentic Media, Milton Keynes. 
Castillo, M., 1992, 'The Philippine missions association: A case study', in J.H. Kraakevik \& D. Welliver (eds.), Partners in the gospel: The strategic role of partnership in world evangelisation, pp. 140-160, Wheaton College, Wheaton, IL.

Conradie, E. \& Field, D., 2016, A rainbow over the land; Equipping Christians to be Earth keepers, A Southern African guide on the church and environmental justice, Biblecor/Bible Media, Wellington.

Eigelaar-Meets, I., Gomulla, C. \& Gelden Huys, A., 2010, 'An emerging strategy of social capital formation: Opportunity and challenge for religious sector', in I. Swart, $\mathrm{H}$. Rocher, S. Green \& J Erasmus (eds.), Religion and development in post-apartheid South Africa: Perspectives for critical engagement, pp. 45-60, Sun Press, Stellenbosch.

Erasmus, J., 2010, 'Meeting unemployment through the faith-based sector - A case study in a South African context', in I. Swart, H. Rocher, S. Green \& J. Erasmus (eds.), Religion and development in post-apartheid South Africa: Perspectives for critical engagement, pp. 377-392, Sun Press, Stellenbosch.

Erasmus, J. \& Mans, G., 2010, 'Churches as service providers for victims of sexual and or violent crimes. A case study 1', in I. Swart, H. Rocher, S. Green \& J. Erasmus (eds.), Religion and development in post-apartheid South Africa: Perspectives for critical engagement, pp. 353-376, Sun Press, Stellenbosch.

Ferris, E., 2005, 'Faith-based and secular humanitarian organizations', International Review of the Red Cross 87(858), 311-325. https://doi.org/10.1017/S1816383 100181366

Hendriks, J.H., 2004, Studying congregations in Africa, Net-ACT, Shumani Mills Digital, Cape Town.

James, R., 2009, What is distinct about FBOs? How European FBOs define and operationalise their faith, Praxis paper 22, INTRAC, Oxford.

Kritzinger, J., 2007, Rethinking ministry: New wine in new wineskins, Christian Literature Fund, Handisa Media, Wellington.
Marais, F., 2017, 'Missional formation and discipleship', in C. Burger, F. Marais \& D. Mouton (eds.), Cultivating missional change: The future of missional churches and missional theology, pp. 372-392, Biblecor/BM, Wellington.

Morgensen, M.S., 2017, 'Missional church in Denmark in cultivating missional change, the future of missional churches and missional theology', in C. Burger, F. Marais \& D. Mouton (eds.), Cultivating missional change: The future of missional churches and missional theology, pp. 124-140, Biblecor/BM, Wellington.

Myers, B., 1999, Walking with the poor. Principles and practices of transformationa development, Orbis, Maryknoll, NY.

Peter, C.B., 1998, 'Beyond a theology of development', African Ecclesial Review 56-67. ATLA Serials.

Pitchford, M. \& Henderson, P., 2008, Making spaces for community development, University of Bristol, Bristol.

Samuel, V. \& Sugden, C., 1999, Mission as transformation: A theology of the whole gospel, Regnum, Oxford.

Smit, D.J., 2008, 'Mainline Protestantism in South Africa and modernity?', Tentative Reflections for Discussion 49(1 \& 2), 92-105.

Swart, I., 2005, 'Networks and partnerships of social justice? The pragmatic turn in the religious social development debate in South Africa', Religion and Theology 12(1), 21-47. https://doi.org/10.1163/157430105X00112

Van Deventer, H.J., 2009, 'Solid foundations for partnership in mission: Missionary perspectives in Paul's Letter to the Romans', in J. Du Plessis, E. Orsmond \& H.J. Van Deventer (eds.), Missionary perspectives in the New Testament, pp. 151-164, Bible Media, Wellington.

Wright, C., 2006, The mission of God: Unlocking the Bible's grand narrative, Intervarsity Press, Oxford. 